\title{
Pengaruh Peranan Sumber Daya Manusia, Pelatihan, Dan Disiplin Kerja Terhadap Kinerja Karyawan
}

\author{
${ }^{1}$ Sri Langgeng Ratnasari, ${ }^{2}$ Berta Saulina L., ${ }^{3}$ Rona Tanjung \\ Universitas Riau Kepulauan \\ Email: ${ }^{1}$ sarisucahyo@yahoo.com, 22bertasaulina6@gmail.com, \\ ronatanjung07@gmail.com
}

(Diterima: Nov 2020; Direvisi: Nov 2020; Dipublikasikan: Jan 2021)

\begin{abstract}
ABSTRAK
Tujuan penelitian ini adalah untuk menganalisis pengaruh peranan sumber daya manusia terhadap kinerja karyawan, untuk menganalisis pengaruh pelatihan terhadap kinerja karyawan dan untuk menganalisis pengaruh disiplin kerja terhadap kinerja karyawan, serta untuk menganalisis pengaruh peranan sumber daya manusia, pelatihan, dan disiplin kerja secara simultan terhadap kinerja karyawan. Populasi penelitian ini adalah karyawan PT. EMI Internasional yang berjumlah 40 orang. Sampel penelitian 40 responden, teknik pengambilan data menggunakan kuisioner. Analisis data menggunakan regresi linier berganda dan uji hipotesis menggunakan SPSS versi 23. Hasil penelitian ini adalah peranan sumber daya manusia berpengaruh signifikan terhadap kinerja karyawan, pelatihan berpengaruh signifikan terhadap kinerja karyawan, disiplin kerja berpengaruh signifikan terhadap kinerja karyawan, dan peranan sumber daya manusia, pelatihan dan disiplin kerja secara simultan berpengaruh signifikan terhadap kinerja karyawan.
\end{abstract}

\section{Kata Kunci: Peranan Sumber Daya Manusia, Pelatihan, Disiplin Kerja, Kinerja Karyawan}




\section{PENDAHULUAN}

Keberhasilan Perusahaaan sangat ditentukan oleh kualitas sumber daya manusia yang bekerja di dalamnya, bukan saja untuk menghadapi persaingan dalam dunia Devisi Elektronik. Salah satu cara untuk mempertahankan kualitas yaitu dengan meningkatkan dan menjaga kinerja karyawan, maka tujuan perusahaan pun akan dapat dicapai secara maksima Kinerja setiap individu dalam organisasi merupakan kunci bagi keberhasilan pencapaian produktivitas karena kinerja merupakan suatu hasil dimana orang orang dan sumber daya yang lain secara bersama sama membawa hasil akhir yang didasarkan pada tingkat mutu dan standar yang telah ditetapkan.

Namun selain sumber daya manusia, pelatihan dan disiplin kerja beberapa hal tersebut mempengaruhi kualitas kinerja karyawan. Ketika Kinerja yang dilakukan karyawan baik maka tujuan perusahaan PT. EMI Internasional dalam meningkatkan keuntungan berjalan dengan baik. Kinerja karyawan merupakan asset terbesar bagi perusahaan. Hasil kinerja karyawan PT. EMI Internasional ini berkaitan dalam hubungan kerja karyawan dengan perusahaan (kontrak kerja), penetapan tempat kerja di area produksi, serta gaji karyawan, jika adanya permasalahan maka hasil kinerja karyawan menjadi menurun dan tujuan tidak tercapai, untuk itu akan merugikan karyawan dan perusahaan.

Sumber daya manusia di PT. Emi Internasional memiliki peran yang sangat penting, untuk tercapainya suatu tujuan perusahaan.
Dalam hal ini sumber daya manusia mencakup keseluruhan mereka yang ikut serta atau terlibat dalam kegiatan operasional perusahaan mulai dari Karyawan hingga Pimpinan perusahaan. Walaupun terdapat perbedaan level, tetapi seluruh sumber daya manusia di perusahaan tersebut memiliki peran yang sama terhadap tercapai atau tidaknya suatu tujuan perusahaan. PT. Emi Internasional memiliki sumber daya manusia (karyawan) untuk melakukan aktivitas produksi mulai barang masuk hingga hasil output dari produksi tersebut merupakan bentuk peranan karyawan. Disisi lain karyawan harus mengejar target yang sudah ditentukan perusahaan demi memenuhi kebutuhan pelanggan atau costumer.

Dari data yang diperoleh di PT. Emi Internasional standar komposisi pendidikan, dapat diketahui bahwa jumlah pendidikan responden yang lulusan SMA sebesar $72 \%$, responden yang lulusan Diploma sebesar $12 \%$ dan responden yang lulusan $\mathrm{S} 1$ sebesar $16 \%$. Hal ini menunjukkan sebagian besar karyawan PT. PT. EMI Internasional memiliki latar pendidikan SMA.

Menurut Arifin (2017) Peranan Sumber Daya Manusia (SDM) dalam perusahaan sangat penting karena sebagai motor penggerak dan pengelola sistem, agar dapat berjalan dengan baik maka pengelolaannya harus memperhatikan aspek-aspek penting seperti pelatihan, pengembangan dan motivasi. Dalam hal ini SDM dijadikan sebagai salah satu indikator penting pencapaian tujuan perusahaan secara efektif dan efisien. SDM merupakan asset perusahaan yang sangat vital, karena 
itu peran dan fungsinya tidak dapat digantikan oleh sumber daya lainnya. SDM dalam perusahaan harus senantiasa beriorentasi terhadap visi, misi, dan tujuan dan sasaran perusahaan. Untuk mencapai visi, misi, dan tujuan tersebut tentu manusia harus memiliki nilai kompetensi dan karakteristik.

Sistem kerja yang dilakukan pada PT. Emi Internasional dilakukan tidak sesuai dengan SOP (Standar Operasional Prosedur) yang ada di perusahaan. Karena fungsinya untuk menggerakkan sumber daya lainnya, sumber daya manusia terutama karyawan membutuhkan stimulus berkelanjutan agar karyawan tetap bisa menjalankan tugas-tugasnya dengan baik.

Dalam hal ini, pelatihan kerja sangat dibutuhkan oleh karyawan. Karena merupakan hal yang sangat penting dalam melaksanakan pekerjaan. Tanpa Pelatihan seorang karyawan tidak akan bekerja dengan maksimal dalam menyelesaikan pekerjaannya dan juga mudah putus asa apabila mengalami kegagalan. Masa kerja seseorang dapat mempengaruhi terlatihnya karyawan, dapat diketahui jumlah responden yang memiliki masa kerja selama $>5$ tahun sebanyak 25 orang, masa kerja $<5$ tahun sebanyak 15 orang. Hal ini menunjukkan sebagian besar karyawan PT. PT. EMI Internasional memiliki masa kerja yang berkisar $>5$ tahun.

Hasil ini diperoleh karena karyawan merasa lebih mudah bekerja ketika telah diberikan pelatihan oleh perusahaan, adanya penguasaan materi dari pelatihan yang di ikuti membuat karyawan merasa ada perkembangan dalam pengetahuan, sehingga hal ini dapat membuat kinerja karyawan semakin meningkat seiring dengan rutinnya pengadaan pelatihan oleh perusahaan. Penelitian ini sejalan dengan penelitan Albertus (2018) dengan judul Pengaruh Komunikasi dan Pelatihan terhadap Kinerja Karyawan.

Permasalahan yang terjadi pada karyawan PT. EMI Internasional adalah masih kurangnya kedisiplinan kerja disebabkan kurangnya kesadaran karyawan menerapkan metode 5S saat bekerja. Selain uraian diatas penggunaan waktu yang kurang efektif dan tanggung jawab karyawan terhadap pekerjaan masih kurang. Ketika perusahaan membutuhkan tenaga kerja diwaktu yang bersamaan karyawan tersebut tidak hadir dalam aktivitasnya sehingga menyebabkan kendala pada produktivitas perusahaan.

Kepatuhan karyawan terhadap peraturan perusahaan dalam melakukan pekerjaan yang ditetapkan tidak sesuai dengan panduan kerja sehingga kelancaran dalam bekerja tidak dapat terbentuk. Karyawan masih kurang efektif dalam penggunaan waktu yang diberikan perusahaan, setiap karyawan diharapkan dapat memanfaatkan waktu dengan baik untuk mencapai target yang diberikan oleh perusahaan. Tanggung jawab yang diberikan kepada setiap individu juga jika tidak sesuai dengan jangka waktu yang ditetapkan perusahaan maka karyawan memiliki tingkat disiplin yang rendah. Penelitian ini sejalan dengan penelitan Sambira (2017) dengan judul Pengaruh Disiplin Kerja, Motivasi Kerja dan Lingkungan Kerja terhadap Kinerja 
Pegawai pada Kantor Penghubung Buton.

Selain sumber daya manusia, pelatihan dan disiplin kerja beberapa hal tersebut mempengaruhi kualitas kinerja karyawan. Ketika Kinerja yang dilakukan karyawan baik maka tujuan perusahaan PT. EMI Internasional dalam meningkatkan keuntungan berjalan dengan baik. Kinerja karyawan merupakan asset terbesar bagi perusahaan. Hasil kinerja karyawan PT. EMI Internasional ini berkaitan dalam hubungan kerja karyawan dengan perusahaan (kontrak kerja), penetapan tempat kerja di area produksi, serta gaji karyawan, jika adanya permasalahan maka hasil kinerja karyawan menjadi menurun dan tujuan tidak tercapai, untuk itu akan merugikan karyawan dan perusahaan.

Adapun rumusan masalah dalam penelitian ini adalah: 1) Apakah Peranan Sumber Daya Manusia (SDM) berpengaruh terhadap Kinerja Karyawan PT. EMI Internasional? 2) Apakah Pelatihan berpengaruh terhadap Kinerja Karyawan PT. EMI Internasional? 3) Apakah Disiplin Kerja berpengaruh terhadap Kinerja Karyawan PT. EMI Internasional? 4) Apakah Peranan Sumber Daya Manusia, Pelatihan, dan Disiplin Kerja berpengaruh terhadap Kinerja Karyawan PT. EMI Internasional?

Berdasarkan rumusan masalah diatas maka penelitian ini bertujuan sebagai berikut: 1) Untuk menguji dan menganalisis pengaruh SDM terhadap kinerja karyawan PT. EMI Internasional. 2) Untuk menguji dan menganalisis pengaruh Pelatihan terhadap Kinerja karyawan PT. EMI
Internasional. 3) Untuk menguji dan menganalisis pengaruh Disiplin Kerja terhadap Kinerja karyawan PT. EMI Internasional. 4) Untuk menguji dan menganalisis Peranan SDM, Pelatihan, dan Disiplin Kerja secara simultan terhadap Kinerja karyawan PT. EMI Internasional.

\section{TINJAUAN PUSTAKA}

\section{Kinerja}

Kinerja adalah suatu hasil kerja yang dicapai seseorang dalam melaksanakan tugas-tugas yang dibebankan kepadanya yang didasarkan atas kecakapan, pengalaman, dan kesungguhan serta waktu, (Mangkunegara 2011)

Mathis dan Jackson (2010) menetapkan standart utama dalam mengukur kinerja karyawan, yaitu sebagai berikut: Quantity of output (kuantitas keluaran), Quality of output (kualitas keluaran), Timelines of output (waktu keluaran), Presences at work (tingkat kehadiran), Efficiency of work completed (efisiensi pekerjaan yang telah diselesaikan), Effectiveness of work completed (efektivitas pekerjaan yang telah diselesaikan).

2. Peranan Sumber Daya Manusia (SDM)

Sumber Daya Manusia merupakan asset perusahaan yang sangat vital, karena itu peran dan fungsinya tidak dapat digantikan oleh sumber daya lainnya. SDM dalam perusahaan harus senantiasa beriorentasi terhadap visi, misi, dan tujuan dan sasaran perusahaan. Untuk mencapai visi, misi, dan tujuan tersebut tentu manusia harus memiliki nilai kompetensi dan karakteristik (Arifin, 2017). 
Menurut Arifin (2017) terdapat lima indikator nilai dan kompetensi peran SDM yaitu: 1 . Motivasi, 2. Sikap atau ciri bawaan, 3. Konsep diri, 4. Pengetahuan, 5. Skills.

\section{Pelatihan}

Pelatihan merupakan sebuah proses mengajarkan pengetahuan dan keahlian serta sikap agar pegawai terampil dan mampu melaksanakan tanggung jawabnya dengan semakin baik sesuai standar (Mangkunegara 2011). Indikator-indikator pelatihan menurut Mangkunegara (2011), diantaranya: Tujuan pelatihan, Materi, Metode yang digunakan, Instruktur, Peserta

\section{Disiplin Kerja}

Disiplin adalah pelatihan karakter untuk menghasilkan pengendalian diri dan kebiasaan untuk patuh pada peraturan yang berlaku, (Wulandari dan Alamanda, 2012). Menurut Hasibuan (2010), ada beberapa indikator dalam disiplin kerja, yaitu: Kepatuhan terhadap peraturan perusahaan, Penggunaan waktu yang efektif, Tanggung jawab dalam pekerjaan, Tingkat absensi.

\section{METODE PENELITIAN}

\section{Populasi}

Populasi yang digunakan dalam penelitian ini adalah karyawan produksi PT. Emi
Internasional, berdasarkan data berjumlah 40 orang.

\section{Sampel}

Sampel penelitian ini menggunakan sensus, teknik sampling jenuh dimana semua anggota populasi dijadikan sampel.

\section{Metode Analisis Data}

Metode pengumpulan data dengan membuat daftar pernyataan (kuesioner) sebanyak 10 pernyataan tentang motivasi dan 10 pernyataan tentang kinerja yang diberikan kepada para karyawan atau responden dan kemudian dikumpulkan kembali. Daftar pernyataan berisi persepsi karyawan terhadap motivasi dalam lingkungan kerja yang dirasakan dan diharapkan oleh guru SMK Yapia Parung-Kab Bogor ini, penulis menggunakan metode deskriptif kuantitatif.

\section{HASIL PENELITIAN \\ Uji Validitas}

Uji validitas digunakan untuk mengukur sah dan valid tidaknya suatu kuesioner. Kuesioner dikatakan valid apabila rhitung > rtabel.Pembagian kuesioner pada seluruh sampel pada penelitian ini yaitu sejumlah 40 responden, sehingga menghasilkan nilai rtabel sebesar 0.312. Dari hasil tersebut, diperoleh rhitung seluruh pernyataan $>\mathrm{r}$ tabel artinya seluruh pernyataan dapat digunakan dalam penelitian ini. Hasil Uji Reliabilitas.

Tabel 1 Hasil Uji Reliabilitas

\begin{tabular}{|c|c|c|c|}
\hline No & Variabel & Cronbach Alpha & N of item \\
\hline 1 & Peranan SDM & 0.940 & 10 \\
\hline 2 & Pelatihan & 0.970 & 10 \\
\hline 3 & Disiplin Kerja & 0.957 & 10 \\
\hline 4 & Kinerja Karyawan & 0.979 & 10 \\
\hline
\end{tabular}


Sumber: Olahan Data, 2020

Berdasarkan data pada Tabel 1, dapat dijelaskan bahwa semua variabel penelitian dinyatakan reliable dimana Cronbach Alpha hitung > Cronbach Alpha yang disyaratkan sebesar 0.6. Artinya terdapat konsistensi jawaban dari responden atas pernyataan variabel peranan sumber daya manusia, pelatihan, disiplin kerja dan kinerja karyawan.

\section{Uji Normalitas}

Pada scatter plot Gambar 1 terlihat titik yang mengikuti garis diagonal menyebar ke semua arah daerah kurva normal.

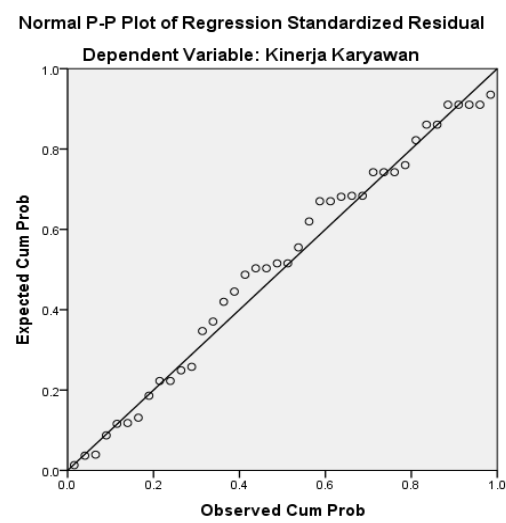

Gambar 1. Hasil Uji Normalitas (P-P Plot)

Sumber: Hasil pengolah data, 2020
Hasil uji normalitas dengan menggunakan normal P-P Plots of Regression menunjukkan bahwa data yang digunakan dalam penelitian ini memiliki distribusi yang normal. Ini dapat diketahui dari adanya kecenderungan data menyebar di sekitar garis diagonal dan mengikuti arah garis diagonal atau grafik histogramnya menunjukkan pola distribusi normal, maka dapat disimpulkan bahwa model regresi memenuhi asumsi normalitas.

\section{Uji Multikolinieritas}

Berdasarkan Tabel 6 menunjukkan bahwa nilai VIF untuk setiap variabel independen kurang dari 10. Nilai VIF dari variabel peranan sumber daya manusia sebesar sebesar 4.113, variabel pelatihan sebesar 5.014 dan variabel disiplin kerja sebesar 4.140. Nilai tolerance untuk setiap variabel independen lebih besar dari 0.10. Variabel peranan sumber daya manusia sebesar 0.243 , variabel pelatihan sebesar 0.199 dan variabel disiplin kerja sebesar 0.242. Sehingga didalam penelitian ini dapat ditarik kesimpulan bahwa tidak terjadi multikolinearitas antar variabel independen.

Tabel 2. Hasil Uji Multikolinieritas

\begin{tabular}{llll}
\hline Model & \multicolumn{2}{c}{ Collinearity Statistics } \\
& Tolerance & VIF \\
\hline \multirow{2}{*}{ 1 Peranan SDM } & .243 & 4.113 \\
& Pelatihan & .199 & 5.014 \\
& Disiplin Kerja & .242 & 4.140 \\
\hline
\end{tabular}

Sumber: Hasil Pengolahan Data, 2020

\section{Uji Heteroskedastisitas}

Pada Grafik 1 Partial Regression Plot terlihat titik-titik pada scatter plot menyebar dan tidak membentuk sebuah pola serta sebarannya diatas dan dibawah angka 0 , hal ini menunjukkan bahwa model tidak terjadi gejala 


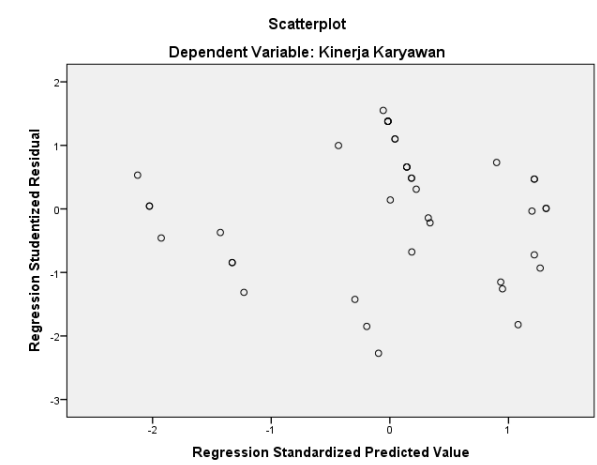

\section{Hasil Uji Regresi Linier Berganda}

Tabel 3. Hasil Regresi Linier Berganda

Coefficients $^{\mathrm{a}}$

\begin{tabular}{lllll}
\hline Model & \multicolumn{2}{l}{ Unstandardized Coefficients } & \multicolumn{2}{l}{$\begin{array}{l}\text { Standardized Coefficients } \\
\text { Beta }\end{array}$} \\
& B & Std. Error & \\
\hline \multirow{4}{*}{1 Constant) } & 19.196 & 2.270 & \\
& Peranan SDM & .774 & .115 & .490 \\
& Pelatihan & .367 & .104 & .284 \\
& Disiplin Kerja & .310 & .088 & .257 \\
\hline
\end{tabular}

a. Dependent Variable: Kinerja Karyawan

Sumber: Hasil Olahan data, 2020

Berdasarkan hasil pengolahan data pada Tabel 3 dapat diperoleh persamaan regresi adalah sebagai berikut.

$\mathrm{Y}=19.196+0.774 \mathrm{X} 1+0.367 \mathrm{X} 2+$ $0.310 \times 3+\mathrm{e}$

Artinya:

1. Konstanta memiliki nilai sebesar 19.196, ini menunjukkan jika peranan sumber daya manusia, pelatihan dan disiplin kerja nilai adalah nol, maka kinerja karyawan memiliki nilai sebesar 19.196.

2. Variabel peranan sumber daya manusia memiliki nilai koefisien regresi sebesar 0.774 ini berarti jika variabel independen lain nilainya tetap atau tidak berubah, maka setiap kenaikan 1 poin atau $1 \%$ variabel peranan sumber daya manusia akan meningkatkan maka kinerja karyawan sebesar 0.774 . Koefisien peranan sumber daya manusia bernilai positif artinya terdapat hubungan positif antara peranan sumber daya manusia dengan maka kinerja karyawan, artinya semakin meningkat nilai peranan sumber daya manusia maka dapat meningkatkan maka kinerja karyawan.

3. Variabel pelatihan memiliki nilai koefisien regresi sebesar 0.367 ini berarti jika variabel independen lain nilainya tetap atau tidak berubah, maka setiap kenaikan 1 poin atau $1 \%$ variabel pelatihan akan meningkatkan maka kinerja karyawan sebesar 0.367. Koefisien pelatihan bernilai positif artinya terdapat hubungan positif antara pelatihan dengan maka kinerja karyawan, artinya semakin meningkat nilai pelatihan maka dapat meningkatkan maka kinerja karyawan.

4. Variabel disiplin kerja memiliki nilai koefisien regresi sebesar 0.310 ini berarti jika variabel independen lain nilainya tetap atau tidak berubah, maka setiap kenaikan 1 poin atau $1 \%$ variabel disiplin kerja akan meningkatkan 
maka kinerja karyawan sebesar 0.249. Koefisien disiplin kerja bernilai positif artinya terdapat hubungan positif antara disiplin kerja dengan maka kinerja karyawan, artinya semakin meningkat nilai disiplin kerja maka dapat meningkatkan maka kinerja karyawan.

\section{PEMBAHASAN \\ PENELITIAN}

HASIL

\section{Hasil Uji Hipotesis}

\section{Uji t (Parsial)}

Hasil uji t menunjukkan bahwa:

a. Nilai $t$ hitung untuk variabel peranan sumber daya manusia sebesar $6.723>1.688 \mathrm{t}$ tabel dan nilai sig $0.000<0.05$. Berdasarkan hasil yang diperoleh maka $\mathrm{H} 0$ ditolak dan $\mathrm{H} 1$ diterima untuk variabel peranan sumber daya manusia, dengan demikian maka secara parsial variabel sumber daya manusia berpengaruh signifikan terhadap kinerja karyawan.

b. Nilai t hitung untuk variabel pelatihan sebesar $3.534>1.688 \mathrm{t}$ tabel dan nilai sig $0.001<0.05$. Berdasarkan hasil yang diperoleh maka $\mathrm{H} 0$ ditolak dan $\mathrm{H} 2$ diterima untuk variabel pelatihan, dengan demikian maka secara parsial variabel pelatihan berpengaruh signifikan terhadap kinerja karyawan.

c. Nilai t hitung untuk variabel disiplin kerja sebesar $3.513>$ $1.688 \mathrm{t}$ tabel dan nilai sig $0.001<$ 0.05. Berdasarkan hasil yang diperoleh maka $\mathrm{H} 0$ ditolak dan $\mathrm{H} 3$ diterima untuk variabel disiplin kerja, dengan demikian maka secara parsial variabel disiplin kerja berpengaruh signifikan terhadap kinerja karyawan.

Hasil Uji $\mathrm{T}$ yang telah dikemukakan diatas menunjukkan bahwa variabel peranan sumber daya manusia, pelatihan, dan disiplin kerja secara parsial berpengaruh terhadap kinerja karyawan PT. EMI Internasional.

\section{Uji F (Simultan)}

Hasil pengujian menunjukkan nilai $\mathrm{F}$ hitung $246.521>2.87 \mathrm{~F}$ tabel dan signikansi $\quad 0.000<0.05, \quad$ maka keputusan yang diambil adalah $\mathrm{H} 0$ ditolak dan $\mathrm{H} 4$ diterima. Kesimpulannya adalah secara simultan variabel peranan sumber daya manusia $(\mathrm{X} 1)$, variabel pelatihan (X2) dan variabel disiplin kerja (X3) berpengaruh signifikan terhadap variabel kinerja karyawan (Y), artinya peranan sumber daya manusia, pelatihan dan disiplin kerja dapat menjelaskan kinerja karyawan PT. EMI Internasional.

Tabel 4

ANOVA $^{\mathrm{a}}$

\begin{tabular}{lllllll}
\hline Model & & Sum of Squares & df & Mean Square F & Sig. \\
\hline \multirow{3}{*}{1} & Regression & 2368.674 & 3 & 789.558 & 246.521 & $.000^{\mathrm{b}}$ \\
& Residual & 115.301 & 36 & 3.203 & & \\
& Total & 2483.975 & 39 & & & \\
\hline
\end{tabular}

a. Dependent Variable: Kinerja Karyawan

b. Predictors: (Constant), Disiplin Kerja, Peranan SDM, Pelatihan

Sumber: Hasil pengolahan data, 2020 


\section{Uji R2 (Determinasi)}

Analisis ini digunakan dalam hubungannya untuk mengetahui jumlah atau presentase sumbangan pengaruh variabel independen dalam model regresi memberikan pengaruh terhadap variabel dependen. Jadi koefisien angka yang ditunjukkan memperlihatkan sejauh mana model yang terbentuk dapat menjelaskan kondisi yang sebenarnya.

Model Summary ${ }^{\mathrm{b}}$

Tabel 5 Koefisien Determinasi

\begin{tabular}{clllc} 
Model & $\mathrm{R}$ & R Square & Adjusted R Square & Std. Error of the Estimate \\
1 & $.977^{\mathrm{a}}$ & .954 & .950 & 1.78964 \\
\hline
\end{tabular}

a. Predictors: (Constant), Disiplin Kerja, Peranan SDM, Pelatihan

b. Dependent Variable: Kinerja Karyawan

Sumber: Hasil Pengolahan SPSS 23, 2020

Berdasarkan hasil pada Tabel 5 diperoleh nilai angka $\mathrm{R}$ sebesar 0.977 , artinya korelasi antara variabel peranan sumber daya manusia, pelatihan dan disiplin kerja terhadap kinerja karyawan sebesar $97.7 \%$. Nilai determinasi (R2) yang diperoleh sebesar 0.954, hal ini berarti presentase sumbangan variabel peranan sumber daya manusia, pelatihan dan disiplin kerja dalam model regresi sebesar $95.4 \%$ dan hubungan yang terjadi adalah sangat kuat, sedangkan sisanya sebanyak 4.6\% dijelaskan oleh variabel lain yang tidak diteliti atau tidak dimasukkan pada penelitian ini.

Berdasarkan hasil analisis di atas maka dapat ditarik kesimpulan bahwa peranan sumber daya manusia, pelatihan dan disiplin kerja secara bersama-sama mampu memberikan sumbangan yang besar atau sangat kuat terhadap kinerja karyawan PT. EMI Internasional. Penelitian ini sejalan dengan penelitan Aswardi (2019) dengan judul Analisis Peranan Sumber Daya Manusia Dalam Pencapaian Kinerja Perusahaan pada PT. Perusahaan Perdagangan Indonesia (Persero) Regional Medan. Penelitian ini sejalan dengan penelitan Albertus (2018) dengan judul Pengaruh Komunikasi dan Pelatihan terhadap Kinerja Karyawan. Studi Kasus pada Unit Pelayanan Teknis Kecamatan Panggang, Gunungkidul Yogyakarta. Penelitian ini sejalan dengan penelitan Sambira (2017) dengan judul Pengaruh Disiplin Kerja, Motivasi Kerja dan Lingkungan Kerja terhadap Kinerja Pegawai pada Kantor Penghubung Buton.

Hasil pada penelitian ini dan berdasarkan hasil olahan data maka diperoleh memiliki nilai $\mathrm{F}$ hitung 246.521> 2.87 F tabel dan signifikansi $\quad 0.000<0.05 \quad$ yang keputusannya $\mathrm{H} 0$ ditolak dan $\mathrm{H} 4$ diterima. Kesimpulannya peranan sumber daya manusia, pelatihan dan disiplin kerja secara simultan berpengaruh positif dan signifikan terhadap kinerja karyawan PT. EMI Internasional. Pada penelitian ini dengan adanya peranan sumber daya manusia yang efektif, pelatihan yang konsisten untuk karyawan dan mampunya seorang karyawan dalam mendisiplinkan dirinya dalam bekerja dapat meningkatkan kualitas kinerja karyawan. Penelitian ini sejalan 
dengan penelitian Sambira (2017), Albertus (2018) dan Aswardi (2019).

\section{KESIMPULAN DAN SARAN}

Berdasarkan hasil dan pembahasan, maka dapat disimpulkan sebagai berikut:

1) Peranan sumber daya manusia berpengaruh positif dan signifikan terhadap kinerja karyawan PT. EMI Internasional.

2) Pelatihan berpengaruh positif dan signifikan terhadap kinerja karyawan PT. EMI Internasional.

3) Disiplin kerja berpengaruh positif dan signifikan terhadap kinerja karyawan PT. EMI Internasional.

4) Peranan sumber daya manusia, pelatihan dan disiplin kerja secara simultan berpengaruh positif dan signifikan terhadap kinerja karyawan PT. EMI Internasional.

\section{DAFTAR PUSTAKA}

Arifin. (2017). Teori dan Kasus Manajemen Sumber Daya Manusia. Jepara: Unisnu Press.

A. Pangarso, P. I. Susanti. (2016). Pengaruh Disiplin Kerja Terhadap Kinerja Pegawai di Biro Pelayanan Sosial Dasar Sekretariat Daerah Provinsi Jawa Barat. Jurnal Manajemen Teori dan Terapan, Vol.9 No. 2.

A. R. Ayu, Gunawan, Harifuddin. (2016). Pengaruh Pendidikan, Pelatihan dan Motivasi Terhadap Kinerja Pegawai Bagian Human dan Protokol Sekretariat Daerah Kabupaten Soppeng. Jurnal Mirai Manajemen, Vol. 1 No. 2.

Albertus, B.W (2018). Pengaruh Komunikasi dan Pelatihan terhadap Kinerja Karyawan"
(Studi Kasus pada Unit Pelayanan Teknis Kecamatan Panggang). Jurnal Administrasi Bisnis. (JAB) Vol.7.No.2.

Aswardi, A., Lubis, Y., \& Lubis, S. (2019). Analisis Peranan Sumber Daya Manusia Dalam Pencapaian Kinerja Perusahaan pada PT. Perusahaan Perdagangan Indonesia (Persero) Regional Medan. AGRISAINS: Jurnal Ilmiah Magister Agribisnis, 1(1), 3137.

Avrianto, Andri. (2012). Analisis Disiplin Kerja pada Rumah Sakit Lancang Kuning Pekan Baru. [Jurnal]. Diakses pada tanggal 11 Juni 2020.

Dessler, G. (2013). Manajemen Sumber Daya Manusia Jilid II. Jakarta: PT.Indeks.

D. I. Suwondo, E. M. Sutanto. (2015). Hubungan Lingkungan Kerja, Disiplin Kerja, dan Kinerja Karyawan. Jurnal Manajemen Kewirausahaan, Vol. 17 No. 2. Fachri, Helman. (2010). FaktorFaktor yang Mempengaruhi Disiplin Kerja Pegawai di Rumah Sakit RI Pontianak Tahun 2010. [Jurnal]. Pontianak: Universitas Muhammadiyah Pontianak.

Fathoni, A. (2012). Organisasi dan Manajemen Sumber Daya Manusia. Jakarta: Rineka Cipta. Handoko. (2013). Manajemen. Edisi Kedua, Cetakan ketigabelas. Yogjakarta: BPFE.

Hasibuan, Malayu P. (2012). Manajemen Sumber Daya Manusia. Jakarta: PT Bumi Aksara.

Idzni, A. Nurul. (2017). Pengaruh Motivasi Dan Pelatihan 
Terhadap Kinerja Karyawan PT. Bank Sumut Kantor Pusat Medan (Studi Kasus Pada Divisi Sumber Daya Manusia Dan Penyelamatan Kredit). Jurnal ekonomi, Vol 8 nomor 2.

Imam Ghozali. (2013). Aplikasi Analisis Multivariate dengan Program IBM SPSS 20 Update PLS Regresi. Semarang: Badan Penerbit Universitas Diponegoro.

Mangkunegara, A. (2012). Evaluasi Kinerja SDM. Bandung: PT. Rafika Aditama.

Mangkunegara, (2013). Manajemen Sumber Daya Manusia. Bandung: Remaja Rosdakarya.

N. Batjo, M. Saleh. (2018). Manajemen Sumber Daya Manusia. Palopo: Aksara Timur.

N. R. Andayani, P. Makian. (2016). Pengaruh Pelatihan Kerja dan Motivasi Kerja Terhadap Kinerja Karyawan PT. PCI Elektronik Internasional' (Studi Kasus Pada Karyawan PT. PCI Elektronik Internasional). Jurnal Akuntansi, Ekonomi, Manajemen Bisnis, Vol. 4, No. 1.

R. D. Tyas, B. S. Sunuharjo. (2018). Pengaruh Disiplin Kerja dan Lingkungan Kerja Terhadap
Kinerja Karyawan (Studi Kasus Pada Karyawan PT. Pertamina (Persero) Refinery Unit IV Cilacap). Jurnal Administrasi Bisnis (JAB). Vol. 62 No. 1.

Sambira, M. (2017). Pengaruh Disiplin Kerja, Motivasi Kerja dan lingkungan Kerja Terhadap Kinerja Pegawai pada Kantor Penghubung Buton (Doctoral dissertation, Tesis dipublikasikan. Program Studi Pascasarjana Universitas Halu Oleo Kendari).

Sugiyono. (2012). Metodologi Penelitian Bisnis. Bandung: Alfabeta.

Sugiyono (2016). Metode Penelitian Kuantitatif, Kualitatif dan $R \& d$. Bandung: Alfabeta.

Suprasetyawati. (2016). Pengaruh Pelatihan dan Motivasi Kerja Terhadap Kinerja Teller dan Customer Service PT. Bank Panen TBK Surabaya." Ejurnal Manajemen Kinerja, Vol. 2 Nomor 1 Tunas Finance Tanjung Pinang. Universitas Maritim Raja Ali Haji Tanjung Pinang. Ejurnal Manajemen 1, Vol.4, no, 1.

Wursanto. (2015). Manajemen Kepegawaian. Yogyakarta: Kanisius. 